\title{
T cell phenotypes associated with insulin resistance: results from the Berlin Aging Study II
}

\author{
Julia Sbierski-Kind ${ }^{1,2^{*}}$ (D), David Goldeck ${ }^{3}$, Nikolaus Buchmann ${ }^{4}$, Joachim Spranger ${ }^{1,5,6}$, Hans-Dieter Volk ${ }^{7,8,9}$, \\ Elisabeth Steinhagen-Thiessen ${ }^{1}$, Graham Pawelec ${ }^{10,11}$, Ilja Demuth ${ }^{1,7,8,9}$ and Dominik Spira ${ }^{1}$
}

\begin{abstract}
Background: Obesity is associated with chronic low-grade inflammation leading to metabolic and cardiovascular diseases, but a subset of obese individuals is considered insulin sensitive (IS). The underlying pathophysiologic mechanisms remain elusive and clinical studies on the relationship between inflammatory markers and metabolically healthy obesity $(\mathrm{MHO})$ are scarce.
\end{abstract}

Methods: In this cross-sectional analysis, we included a sample of 437 older participants (60-84 years) from the Berlin Aging Study II (BASE-II). Peripheral blood mononuclear cells were isolated, immune cell subsets were analyzed with multiparameter flow cytometry and systemic cytokine levels were measured. Immune cell parameters were correlated with metabolic measures and multiple linear regression analysis was conducted and adjusted for various demographic and clinical factors.

Results: We found that frequencies of naïve and memory $C D 4^{+}$and $C D 8^{+} T$ cells inversely correlated with measures for insulin sensitivity in the older population. Moreover, the percentages of naïve $\mathrm{CD} 4^{+}$and $\mathrm{CD} 8^{+} \mathrm{T}$ cells were significantly higher, whereas activated T cells and IL-6 levels were lower in IS compared to insulin resistant (IR) obese individuals. The percentages of naïve $\mathrm{CD}^{+}$and $\mathrm{CD}^{+} \mathrm{T}$ cells were predictive for impaired insulin sensitivity ( $B=0.16, p=0.01$ and $B=0.11, p=0.04$ ), and the association of naive $C D 4^{+} T$ cells with insulin sensitivity persisted after multivariate adjustment $(B=0.14, p=0.02$ ).

Conclusions: These findings support the hypothesis that parameters of systemic inflammation can differentiate IS from IR obese individuals that are at higher risk for cardiometabolic diseases and may have clinical implications with regard to obesity treatment stratification.

Trial registration: DRKS00009277. Registered 31 August 2015 - Retrospectively registered.

Keywords: Obesity, Insulin resistance, Systemic inflammation, Aging, T cell senescence

\footnotetext{
* Correspondence: Julia.Sbierski-Kind@ucsf.edu

${ }^{1}$ Charité-Universitätsmedizin Berlin, Corporate Member of Freie Universität Berlin, Humboldt-Universität zu Berlin, and Department of Endocrinology and Metabolism, Berlin Institute of Health, Chariteplatz 1, 10117 Berlin, Germany ${ }^{2}$ Present Address: Dept. of Laboratory Medicine, University of California, San Francisco, HSW1201U, Box 0451, 513 Parnassus Ave, San Francisco, CA 94143-0451, USA

Full list of author information is available at the end of the article
}

(c) The Author(s). 2020 Open Access This article is licensed under a Creative Commons Attribution 4.0 International License, which permits use, sharing, adaptation, distribution and reproduction in any medium or format, as long as you give appropriate credit to the original author(s) and the source, provide a link to the Creative Commons licence, and indicate if changes were made. The images or other third party material in this article are included in the article's Creative Commons licence, unless indicated otherwise in a credit line to the material. If material is not included in the article's Creative Commons licence and your intended use is not permitted by statutory regulation or exceeds the permitted use, you will need to obtain permission directly from the copyright holder. To view a copy of this licence, visit http://creativecommons.org/licenses/by/4.0/. The Creative Commons Public Domain Dedication waiver (http://creativecommons.org/publicdomain/zero/1.0/) applies to the data made available in this article, unless otherwise stated in a credit line to the data. 


\section{Background}

Obesity, defined by the accumulation of abnormal or excess body fat, is a worldwide epidemic, with increasing prevalence in developed and developing countries and with a serious impact on human health. Worldwide, over 2 billion people are overweight or obese [1]. Obesity is a major risk factor for metabolic diseases, such as type 2 diabetes, dyslipidemia, fatty liver disease and cardiovascular diseases, such as hypertension, peripheral artery disease, myocardial infarction, stroke, and cancer [2-5]. .However, the large variation in the individual risk to develop insulin resistance or other obesity-related comorbidities has led to the concept of MHO [6]. Whereas the majority of obese people develop insulin resistance, about $20 \%$ are considered metabolically healthy with an age- and gender-dependent prevalence, and, thus, seem to be protected from insulin resistance [7]. The diagnosis of obesity and treatment options are based on the body mass index (BMI), which fails to reliably predict the predisposition to cardiometabolic diseases $[8,9]$. Individuals with $\mathrm{MHO}$ have been defined by the absence of metabolic impairments or cardiovascular diseases, due to the lack of standardized $\mathrm{MHO}$ criteria. However, most recently the BioShare-EU project has proposed a unified definition of $\mathrm{MHO}$, comparing clinical and metabolic factors of 10 population-based cohort studies from 7 countries, including fasting blood glucose [10, 11]. To guide personalized and risk-stratified obesity treatment, there is a critical need to investigate differences between MHO and metabolically unhealthy obesity, but informative studies are, thus far, very limited [7]. Obesity is associated with systemic and adipose tissue inflammation [12-14]. Excessive energy intake is thought to be a major contributor of obesity and leads to the accumulation of lipids in adipocytes and the expansion of adipose tissue. Hypertrophic adipocytes can produce pro-inflammatory cytokines, such as IL-6 and TNF, which leads to increased vascular permeability, circulating monocytes and the recruitment of cytotoxic $\mathrm{T}$ cells, initiating an inflammatory process that promotes insulin resistance $[14,15]$. Recently, it has been reported that increased systemic and adipose tissue inflammation can differentiate obese women with impaired glucose tolerance from obese women with normal glucose tolerance [16]. Blüher and colleagues have shown that macrophage infiltration into visceral adipose tissue, higher inflammatory parameters and circulating adipokines can predict insulin resistance in morbidly obese patients [17]. However, only limited and partially discordant data are available on the association of systemic and adipose tissue inflammation with insulin resistance, especially in older patients.

In the present study, we focused on identifying relationships between the distribution of peripheral immune cell subsets, cytokine levels, and metabolic measures in a large non-clinical sample of older adults. Using data from BASE-II, we tested the hypothesis that individuals with obesity and insulin resistance have increased proinflammatory cytokines correlating with activated $\mathrm{T}$ cell subsets. The aim was to compare a cohort of obese participants with and without insulin resistance and a cohort of non-obese participants with and without insulin resistance.

\section{Results \\ Characteristics of the sample}

We analyzed 437 of 1671 older participants (60-84 years) of the BASE-II study, medically assessed at baseline, based on the availability of immunological parameters. The sample analyzed in this study was composed of participants with an equal gender distribution. Table 1 shows the median age, BMI, metabolic measurements (HbA1c, insulin sensitivity index ( ISI $_{\mathrm{OGTT}}$ ), homeostasis model of assessment for insulin resistance (HOMA-IR)), glucose and insulin parameters measured in oral glucose tolerance tests (OGTT) and lipid parameters), hematologic parameters, and plasma C-reactive protein (CRP) levels of male and female participants. All hematologic parameters and CRP levels were within the normal range (NR). Obesity was noted in 28 of 181 men (15.5\%) and 49 of 256 women (19.1\%) (defined as BMI $>30 \mathrm{~kg} / \mathrm{m}^{2}$ ), whereas $6.6 \%$ (women) and $11 \%$ (men) were diagnosed with type 2 diabetes. Participants with type 2 diabetes were ruled out for further analyses. However, $31.8 \%$ of the men and $28.8 \%$ of the women were considered IR at least to some extent, with insulin resistance being defined as $\mathrm{ISI}_{\mathrm{OGTT}}<4$. Surprisingly, only $50 \%$ of all obese participants analyzed in this study had an $\mathrm{ISI}_{\mathrm{OGTT}}<4$, and only $32 \%$ of all obese participants were considered truly IR, as assessed by HOMA-IR (HOMA-IR > 2.9).

\section{Impaired insulin sensitivity is associated with increased T cell senescence}

As expected, the BMI was negatively associated with ISI $_{\text {OGTT }}$ in both male and female participants (Fig. 1a). The ISI $_{\text {OGTT }}$ also correlated negatively with the total number of leukocytes, obtained from complete blood count results (Fig. 1b), in line with previous results from another study of ours [18]. To assess the association of metabolic parameters (BMI, HOMA-IR, ISI ${ }_{\text {OGTT }}$ ) with systemic leukocyte subpopulations, we analyzed multiparameter flow cytometric data derived from blood samples of older participants. To analyze gender-specific differences, we here calculated each correlation independently for men and women. Whereas the percentages of major mononuclear leukocyte subsets $\left(\mathrm{CD}^{+}{ }^{+}\right.$and $\mathrm{CD}^{+} \mathrm{T}$ cells, $\mathrm{CD} 19^{+}$ $\mathrm{B}$ cells, $\mathrm{CD} 56^{+} \mathrm{NK}$ cells, and $\mathrm{CD} 14^{+}$monocytes) did not significantly correlate with BMI, HOMA-IR or

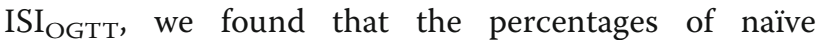


Table 1 Characteristics of the BASE-II participants included in the present study

\begin{tabular}{|c|c|c|}
\hline & Men $(n=181)$ & Women $(n=256)$ \\
\hline Age [years] & $70(67-73)$ & $68(66-70)$ \\
\hline BMI [NR $\left.18-25 \mathrm{~kg} / \mathrm{m}^{2}\right]$ & $26.9(25.0-29.0)$ & $25.8(23.4-28.6)$ \\
\hline Body weight $[\mathrm{kg}]$ & $82.1(76.4-90.5)$ & $68.0(62.0-76.3)$ \\
\hline Height [cm] & $175.7(171.0-180.0)$ & $163.2(158.9-168)$ \\
\hline $\mathrm{HbA} 1 \mathrm{c}[\mathrm{NR}<5.7 \%]$ & $5.5(5.2-5.7)$ & $5.4(5.2-5.7)$ \\
\hline HOMA-IR $(\mathrm{NR}<1.9)$ & $2.0(1.4-3.0)$ & $1.7(1.2-2.5)$ \\
\hline$|S|_{O G T}(N R>4)^{a}$ & $5.6(3.3-8.7)$ & $5.7(3.8-8.3)$ \\
\hline Fasting PG (mg/dL) & $102.5(88.0-125.0)$ & $104.0(89.0-124.0)$ \\
\hline PG in $75-\mathrm{g}$ OGTT at $120 \mathrm{~min}(\mathrm{mg} / \mathrm{dL})$ & $94.0(87.0-102.0)$ & $89.0(84.0-96.0)$ \\
\hline Fasting Insulin in 75-g OGTT (mg/dL) & $9.0(6.3-12.3)$ & $7.6(5.7-10.4)$ \\
\hline Insulin in 75-g OGTT at $120 \mathrm{~min}(\mathrm{mg} / \mathrm{dL})$ & $42.9(25.6-72.4)$ & $44.9(29.7-67.3)$ \\
\hline Triglycerides (NR </= 200 mg/dL) & $104(77-143)$ & $91(73-119)$ \\
\hline $\begin{array}{l}\mathrm{HDL} \text { cholesterol (NR male/female =/> } \\
35 / 45 \mathrm{mg} / \mathrm{dL} \text { ) }\end{array}$ & $53(45-65)$ & $70(57-79)$ \\
\hline LDL cholesterol (NR < 130 mg/dL) & $122(100-147)$ & $136(112-162)$ \\
\hline Cholesterol (NR < $200 \mathrm{mg} / \mathrm{dL})$ & $201(177-228)$ & $232(202-256)$ \\
\hline Obesity [n, \%] & $28(15.5)$ & 49 (19.1) \\
\hline $\mathrm{T} 2 \mathrm{D}[\mathrm{n}, \%]$ & $20(11.0)$ & $17(6.6)$ \\
\hline HOMA-IR > $1.9[n, \%]$ & $21(12.1)$ & $22(9.1)$ \\
\hline$|S|_{O G T}<4[n, \%]^{a}$ & $51(31.8)$ & $65(28.6)$ \\
\hline $\mathrm{CRP}(\mathrm{NR}<5 \mathrm{mg} / \mathrm{L})$ & $1.2(0.7-2.3)$ & $1.2(0.6-2.0)$ \\
\hline Basophils (NR 0-0.2 G/L) & $0.05(0.05-0.05)$ & $0.05(0.05-0.05)$ \\
\hline Eosinophils (NR 0.02-0.5 G/L) & $0.18(0.11-0.24)$ & $0.15(0.10-0.220)$ \\
\hline Leukocytes (NR 3.9-10.5 G/L) & $5.7(4.7-6.7)$ & $5.5(4.6-6.4)$ \\
\hline Monocytes (NR 0.1-0.9 G/L) & $0.45(0.36-0.53)$ & $0.35(0.29-0.43)$ \\
\hline Neutrophils (NR 1.5-7.7 G/L) & $3.2(2.7-4.0)$ & $3.1(2.5-3.7)$ \\
\hline
\end{tabular}

Categorical data are presented as percentages. None of the continuous variables were normally distributed; thus, values are presented as median and interquartile range. BMI body mass index, HOMA-IR homeostasis model assessment of insulin resistance. $I S I_{O G T}$ insulin sensitivity index, $N R$ normal range, OGTT oral glucose tolerance test, $P G$ plasma glucose, $T 2 D$ type 2 diabetes. ${ }^{\mathrm{I}} \mathrm{ISI} \mathrm{OGTT}_{\mathrm{T}}$ was not assessed for participants with type 2 diabetes

$\left(\mathrm{CD} 45 \mathrm{RA}^{+} \mathrm{CCR} 7^{+} \mathrm{CD} 27^{+} \mathrm{CD} 28^{+}\right) \mathrm{CD}^{+}$and $\mathrm{CD}^{+}{ }^{+} \mathrm{T}$ cell subsets (the latter only within the female subgroup) were positively associated with ISI $_{\text {OGTT }}$ and negatively associated with HOMA-IR in older participants, whereas the percentage of central memory $\left(\mathrm{CD} 45 \mathrm{RA}^{-} \mathrm{CD} 27^{+} \mathrm{CD} 28^{+}\right)$ $\mathrm{CD} 4^{+} \mathrm{T}$ cells was negatively associated with $\mathrm{ISI}_{\mathrm{OGTT}}$ and positively associated with HOMA-IR (Fig. 1c-e, Supplementary Table 1). However, neither men nor women exhibited a significant correlation between the percentage of central memory $\mathrm{CD}^{+} \mathrm{T}$ cells and the $\mathrm{ISI}_{\mathrm{OGTT}}$ (Fig. 1f). The percentage of effector memory $\left(\mathrm{CD} 45 \mathrm{RA}^{-} \mathrm{CD} 27^{-} \mathrm{CD} 28^{-}\right)$ $\mathrm{CD}^{+} \mathrm{T}$ cells correlated positively with HOMA-IR, but other $\mathrm{T}$ cell subsets (exhausted $\mathrm{PD} 1^{+} \mathrm{T}$ cells or terminally differentiated effector memory $\mathrm{T}$ cells) did not show significant associations with metabolic measures (Supplementary Table 1). While regulatory $\mathrm{T}$ (Treg) cells have been reported to play a role in regulating obesity-induced adipose tissue inflammation [19], the percentage of circulating
FoxP3 ${ }^{+} \mathrm{CD} 25^{\text {high }}$ Treg cells within the $\mathrm{CD} 4^{+} \mathrm{T}$ cell subset

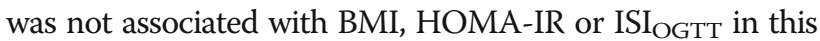
study (Fig. 1g, Supplementary Table 1). However, CD8 ${ }^{+}$ FoxP ${ }^{+}$Treg cells, which have been reported recently to be critical in prevention of autoimmune-mediated diabetes, correlated positively with BMI (data not shown). The different subsets of B cells did not correlate significantly with metabolic measures. Whereas the percentage of $\mathrm{CD} 14^{-} \mathrm{CD} 16^{+}$monocytes correlated inversely with HOMA-

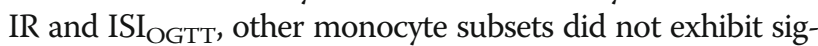
nificant correlations (Supplementary Table 1). Additionally, we correlated cytokine levels (IL-6, IL-10, TNF, IL-1ß) with metabolic measures. As described previously [20], the seminal inflammatory marker IL-6 was negatively associated with $\mathrm{ISI}_{\mathrm{OGTT}}$ in female participants (Fig. 1h), but the associations between IL-10, TNF, IL-1ß and metabolic measures were not significant (data not shown). CD57 has been proposed as a marker for $\mathrm{T}$ cell senescence, as its expression is associated with impaired proliferative capacity and other characteristics of senescence [21]. However, CD57 can also define activated immunoregulatory-like cells [22]. Here, we found a positive association of CD57 expression on central memory $\mathrm{CD}^{+}{ }^{+} \mathrm{T}$ cells with $\mathrm{BMI}$, whereas $\mathrm{CD} 57^{+}$effector memory $\mathrm{CD}^{+} \mathrm{T}$ cells correlated positively with HOMA-IR (Supplementary Table 1). With age, the distribution of circulating $\mathrm{T}$ cells at different stages of differentiation changes drastically, as a result of the minimal production of naive $\mathrm{T}$ cells, and the accumulation of senescent-like $\mathrm{CD} 28^{-} \mathrm{CD} 57^{+} \mathrm{CD} 8^{+} \mathrm{T}$ cells, which have been shown to be associated with reduced immune response to pathogens in the elderly [22]. This could contribute to increased severity of infections in the older population [23]. Taken together, our findings thus imply that insulin resistance is associated with a higher "age" of circulating $\mathrm{T}$ cells. Since the serostatus of CMV can affect the phenotype of immune cell subsets as well [24], we additionally correlated the BMI and

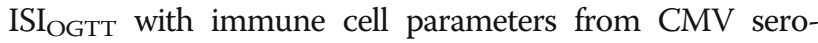
negative and seropositive participants. We found that the correlation coefficients were influenced by the CMV serostatus and that some significant correlations between $\mathrm{T}$ cell subsets, BMI and ISI $\mathrm{OGTT}$ were found in $\mathrm{CMV}^{+}$, but not $\mathrm{CMV}^{-}$participants.

\section{T cells have a more activated phenotype in IS versus IR obese individuals}

To better characterize the immunological differences between IS, who are considered metabolically healthy, and IR (considered metabolically unhealthy) obese and nonobese participants of this study, we stratified the cohort

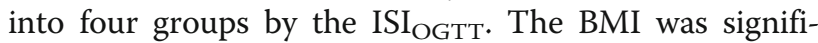
cantly lower in non-obese IS participants (Fig. 2a) but did not differ significantly between IS and IR obese participants. As expected, ISI $\mathrm{OGTT}_{\mathrm{G}}$, HOMA-IR and HbA1c were significantly different between IS and IR obese and 


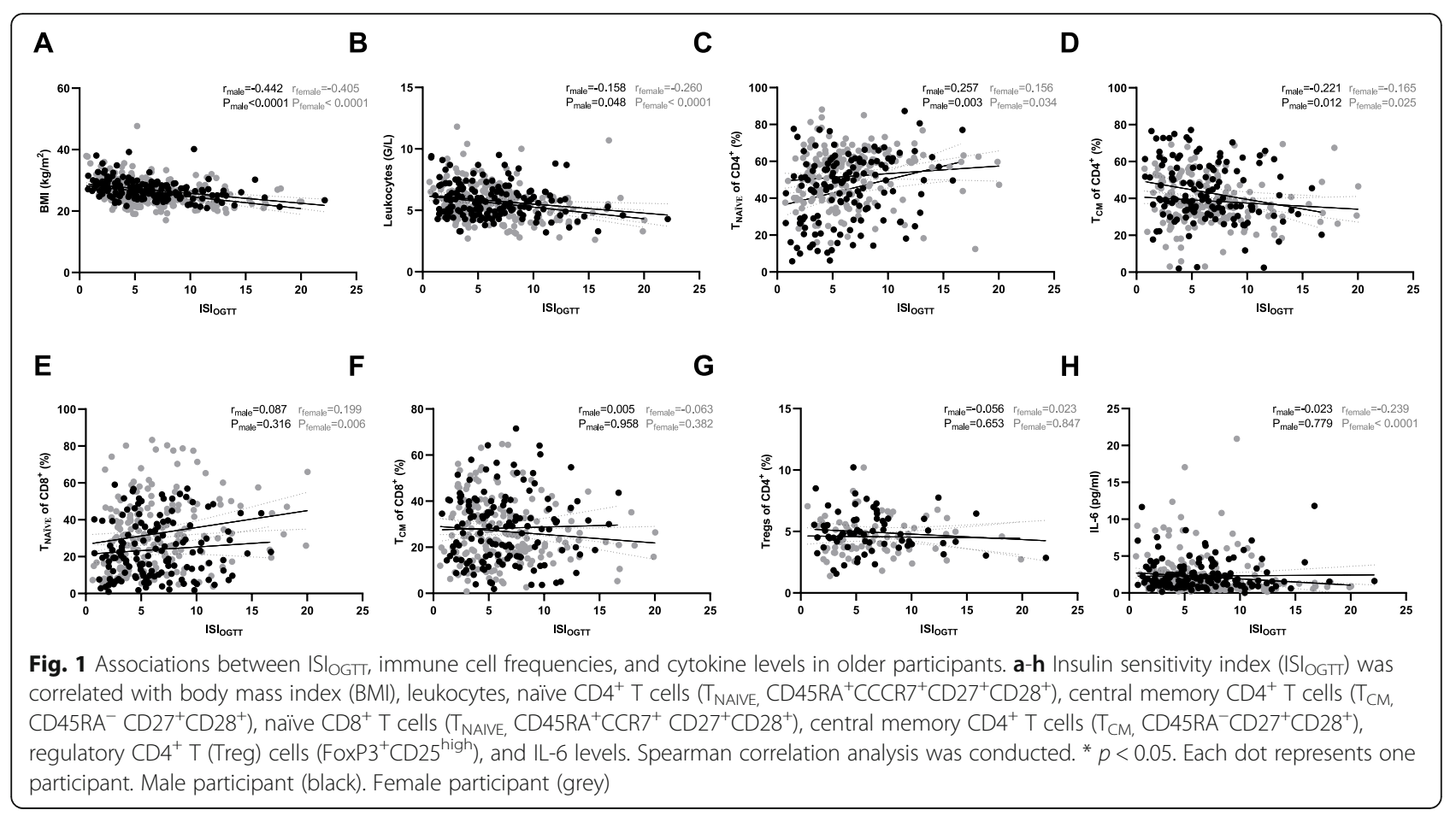

non-obese participants (Fig. 2b, c and e), whereas CRP, triglyceride and LDL cholesterol levels, and age did not differ significantly between groups (Fig. $2 \mathrm{~d}$ and $\mathrm{f}-\mathrm{h}$ ). The frequencies of naïve $\mathrm{CD}^{+} \mathrm{T}$ cells were significantly higher in obese and non-obese IS compared to IR participants, whereas the frequencies of effector memory and $\mathrm{CD} 7^{+}$antigen-experienced and differentiated $\mathrm{CD} 8^{+} \mathrm{T}$ cells were significantly lower in obese IS compared to IR individuals (Fig. 2i-k). Additionally, IL-6 levels, which have previously been reported to promote insulin resistance [20], were higher in obese IR than IS individuals (Fig. 2l). In the $\mathrm{CD}^{+} \mathrm{T}$ cell compartment, frequencies of naïve $\mathrm{CD}_{4}^{+} \mathrm{T}$ cells were higher and frequencies of central memory $\mathrm{CD} 4^{+} \mathrm{T}$ cells were lower in IS versus IR non-obese individuals, while we did not see any significant differences in the obese group (Fig. 2m-o, Supplementary Table 3). No significant differences between groups were found for other T cell subsets, B cells, NK cells, monocytes or $\mathrm{CD}^{+}$Treg cells (Supplementary Table 3). In addition, the levels of the anti-inflammatory cytokine IL-10 (Fig. 2p), TNF and IL-1ß were not significantly different in the obese and non-obese subgroups (Supplementary Table 4). TNF and IL- $1 ß$ were undetectable in some participants, and these were excluded in further studies. These findings suggest that senescence of circulating $\mathrm{T}$ cells reflects a major difference between IS and IR participants in both obese and non-obese subgroups.
The percentage of naïve $\mathrm{CD}^{+}$and $\mathrm{CD}^{+} \mathrm{T}$ cells predicts impaired insulin sensitivity

Next, we tested the association of ISI $_{\text {OGTT }}$ with systemic leukocyte subsets and cytokine levels in multivariable linear regression models. The frequencies of $\mathrm{T}$ cells, Treg cells, monocytes, B cells, and NK cells were not sig-

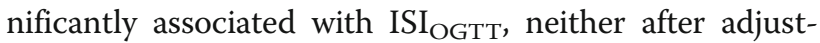
ment for sex and BMI (model 1) nor with additional adjustment for the morbidity index and cytomegalovirus (CMV) status (model 2). More details of these results that are in line with our findings that the proportions of major innate and adaptive leukocyte subsets ( $T$ cells, Treg cells, monocytes, B cells, and NK cells) were not significantly different in obese or non-obese IR and IS participants can be found in Supplementary Table 5. T stem cell-like memory $\mathrm{T}$ cells (TSCM, defined as CD45RA ${ }^{+} \mathrm{CCR} 7{ }^{+} \mathrm{CD} 27^{+} \mathrm{CD} 28^{+} \mathrm{CD} 95^{+}$) were also not significantly associated with ISI $_{\text {OGTT }}$ (Supplementary Table 5). Table 2 summarizes the regression analyses of naïve, central, effector, and terminally differentiated effector memory $\mathrm{CD}^{+}$and $\mathrm{CD}^{+} \mathrm{T}$ cells on $\mathrm{ISI}_{\mathrm{OGTT}}$. Whereas central and terminally differentiated effector memory $\mathrm{CD}^{+}$and $\mathrm{CD}^{+} \mathrm{T}$ cells did not predict $\mathrm{ISI}_{\mathrm{OGTT}}$, naïve $\mathrm{CD}^{+}$and $\mathrm{CD} 8^{+} \mathrm{T}$ cells, and central memory $\mathrm{CD}^{+} \mathrm{T}$ cells were significantly associated with

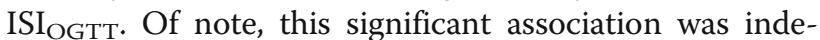
pendent of sex, BMI, and even after adjustment for the morbidity index and CMV status in model 2, the 


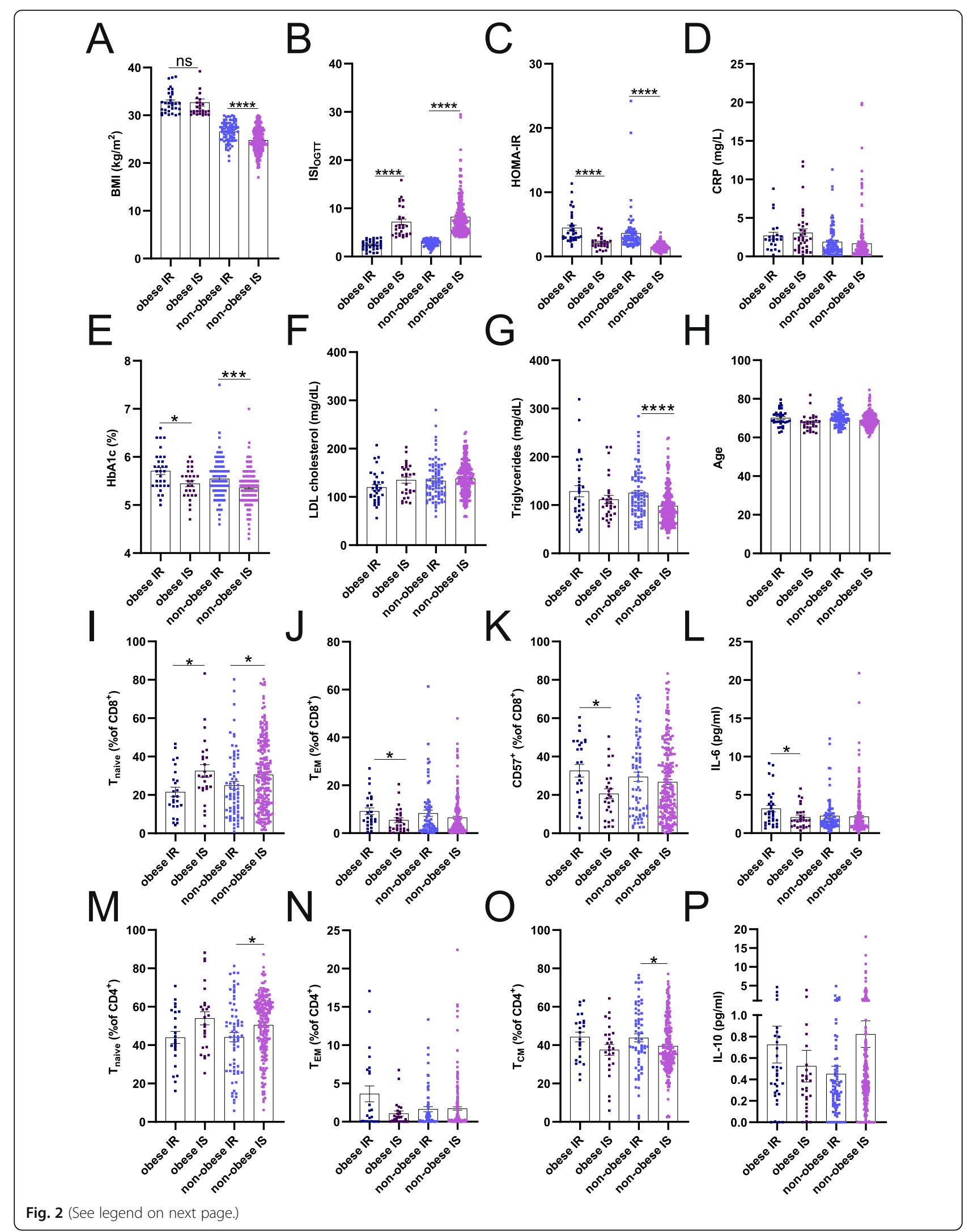


(See figure on previous page.)

Fig. 2 Comparison of the distributions of metabolic parameters, immune cell subpopulation proportions, and cytokine levels in obese and nonobese insulin resistant (IR) and insulin sensitive (IS) participants. a-p Mann-Whitney $U$ test was conducted to estimate differences between obese $\left(\mathrm{BMI}>30 \mathrm{~kg} / \mathrm{m}^{2}\right) \mathrm{IS}$ and IR, and non-obese $\left(\mathrm{BMI}<30 \mathrm{~kg} / \mathrm{m}^{2}\right)$ IS and IR participants. a-h BMI (a), ISl $\mathrm{OGTT}$ (b), HOMA-IR (c), CRP levels (d), HbA1c (e), $\mathrm{LDL}$ cholesterol (f), triglycerides $(\mathbf{g})$, and age $(\mathbf{h})$ were compared between groups. i-p (i) Naïve $\mathrm{CD}^{+}\left(\mathrm{T}_{\mathrm{NAIVE}}, \mathrm{CD}_{5} \mathrm{RA}^{+} \mathrm{CCR} 7^{+} \mathrm{CD} 27^{+} \mathrm{CD} 28^{+}\right),(\mathbf{j})$

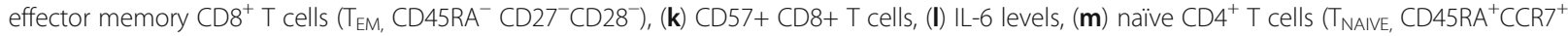
$\left.\mathrm{CD}_{2} 7^{+} \mathrm{CD} 28^{+}\right)$, (n) effector memory CD4 ${ }^{+} \mathrm{T}$ cells $\left(\mathrm{T}_{\mathrm{EM}}, \mathrm{CD} 45 \mathrm{RA}^{-} \mathrm{CD} 27^{-} \mathrm{CD} 28^{-}\right)$, (o) central memory $\mathrm{CD} 4^{+} \mathrm{T}$ cells $\left(\mathrm{T}_{\mathrm{CM}}, \mathrm{CD} 45 \mathrm{RA}^{-} \mathrm{CD} 27^{+} \mathrm{CD} 28^{+}\right),(\mathbf{p})$ and IL-10 levels were compared between groups. Data are shown as mean \pm SEM. ${ }^{*} p<0.05 .{ }^{* * *} p<0.0001$

associations of naïve $\mathrm{CD} 4^{+} \mathrm{T}$ cells and $\mathrm{ISI}_{\mathrm{OGTT}}$ remained significant (Table 2, Supplementary Table 5). We replicated these findings using an additional binary logistic regression model (Supplementary Table 6). To account for potential selectivity based on high age, we also added a sensitivity analysis, and ruled out participants, that were aged 80 years or older ( 8 participants, age $80-84$ years). None of those participants were obese and the results remained unchanged (Supplementary Table 7). CMV was included in this analysis because latent infection with this herpesvirus strongly influences circulating naïve and memory $\mathrm{T}$ cell phenotypes [25]. Circulating IL-6 and IL-10 levels were not significantly associated with ISI $_{\text {OGTT }}$ (data not shown). Taken together, these data indicate that the differentiation and activation state of $\mathrm{CD}^{+}$and $\mathrm{CD}^{+} \mathrm{T}$ cells is strongly associated with insulin resistance.

\section{Discussion}

The prevalence of obesity has dramatically increased in all age groups in recent years, but obesity rates among older adults are even higher. Increasing age has been shown to be associated with lower prevalence of $\mathrm{MHO}$ [10]. Recently, it has been reported that obesity-related comorbidities and conditions mirror those of aging and age-related diseases [26]. Obesity and aging can lead to chronic low-grade inflammation and an increased incidence of chronic inflammatory diseases due to dysregulated immune responses [27-31]. Macrophages seem to be primarily involved in obesity-associated inflammation, changing their phenotype from "alternatively activated" to "inflammatory" macrophages [32, 33]. Moreover, other components of the innate immune system, mast cells, neutrophils, and dendritic cells, have been shown to exacerbate insulin resistance [34-36], whereas eosinophils and type 2 innate lymphoid cells can protect against adipose tissue and islet inflammation [35]. More recent work focused on adaptive immune responses in obesity-induced systemic and adipose tissue inflammation. T cells, including $\mathrm{CD}^{+} \mathrm{T}$ cells, Th1, Th17, as well as B cells, can exacerbate inflammation, whereas Treg cells and Th2 cells can dampen inflammation and protect against insulin resistance [37-39]. Several human studies investigated the association of inflammatory parameters with impaired insulin sensitivity. In particular, it has been found that the helper $\mathrm{T}$ cell composition in peripheral blood correlates significantly with the HOMA-IR [40] and other measures of adiposity, inflammation and glucose intolerance, whereas circulating Treg cells were reduced in obese subjects, and might identify individuals at increased risk for cardiovascular comorbidities [41, 42]. Moreover, a distinct phenotype

Table 2 Association of immune cell subsets with ISI OGT

\begin{tabular}{|c|c|c|c|c|c|c|c|}
\hline & & \multicolumn{6}{|c|}{ ISI $^{\text {OGTT }}[95 \% \mathrm{CI}]$} \\
\hline & & \multicolumn{3}{|c|}{ model 1} & \multicolumn{3}{|c|}{ model 2} \\
\hline & & $\beta$ & SE & $\mathrm{p}$ & B & SE & $\mathrm{p}$ \\
\hline \multirow{7}{*}{ 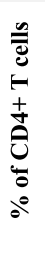 } & naïve $\mathrm{CD}^{+} \mathrm{T}$ cells $\left(\mathrm{CD} 45 \mathrm{RA}^{+} \mathrm{CCR} 7^{+} \mathrm{CD} 7^{+} \mathrm{CD}{ }^{+}\right)$ & 0.16 & 0.16 & 0.01 & 0.14 & 1.4 & 0.02 \\
\hline & central memory $\mathrm{CD} 4+\mathrm{T}$ cells $\left(\mathrm{CD}^{-} \mathrm{RA}^{-} \mathrm{CD}^{-} 7^{+} \mathrm{CD}^{-} 8^{+}\right)$ & -0.12 & 1.53 & 0.03 & -0.1 & 1.62 & 0.09 \\
\hline & effector memory $\mathrm{CD}^{+}{ }^{+} \mathrm{T}$ cells $\left(\mathrm{CD}^{2} 5 \mathrm{RA}^{-} \mathrm{CD} 27^{-} \mathrm{CD} 28^{-}\right)$ & -0.09 & 4.72 & 0.1 & -0.08 & 5.12 & 0.19 \\
\hline & TEMRA CD4 $^{+} \mathrm{T}$ cells $\left(\mathrm{CD} 45 \mathrm{RA}^{+} \mathrm{CCR}{ }^{-} \mathrm{CD} 27^{-} \mathrm{CD} 28\right)$ & -0.03 & 5.5 & 0.59 & -0.04 & 6.42 & 0.56 \\
\hline & $\mathrm{CD} 4 \mathrm{RA}^{+} \mathrm{CD}^{+}{ }^{+} \mathrm{T}$ cells & 0.14 & 1.31 & 0.01 & 0.12 & 1.38 & 0.04 \\
\hline & $\mathrm{CD57}^{+} \mathrm{CD}^{+} \mathrm{T}$ cells & -0.06 & 3.63 & 0.3 & -0.07 & 4.18 & 0.29 \\
\hline & naïve $\mathrm{CD8}^{+} \mathrm{T}$ cells $\left(\mathrm{CD}^{2} 5 \mathrm{RA}^{+} \mathrm{CCR}^{+} \mathrm{CD}^{+} 7^{+} \mathrm{CD28}^{+}\right)$ & 0.11 & 0.11 & 0.04 & 0.11 & 1.35 & 0.08 \\
\hline \multirow{6}{*}{ 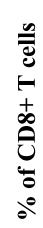 } & central memory $\mathrm{CD8}+\mathrm{T}$ cells $\left(\mathrm{CD}^{-} \mathrm{RAA}^{-} \mathrm{CD}^{-} 7^{+} \mathrm{CD}^{-} 8^{+}\right)$ & -0.02 & 1.5 & 0.75 & -0.02 & 1.74 & 0.8 \\
\hline & 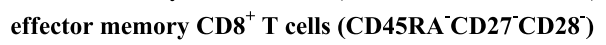 & -0.09 & 2.54 & 0.09 & -0.01 & 2.76 & 0.09 \\
\hline & 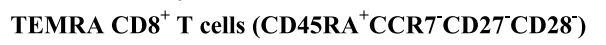 & -0.03 & 1.21 & 0.58 & -0.02 & 1.48 & 0.73 \\
\hline & $\mathrm{CD} 4 \mathrm{RA}^{+} \mathrm{CDB}^{+} \mathrm{T}$ cells & 0.08 & 1.31 & 0.15 & 0.08 & 1.42 & 0.15 \\
\hline & $\mathrm{CD57}^{+} \mathrm{CD8}^{+} \mathrm{T}$ cells & -0.04 & 1.13 & 0.47 & -0.05 & 1.35 & 0.48 \\
\hline & $\mathrm{PD}-1^{+} \mathrm{CD8}^{+} \mathrm{T}$ cells & -0.01 & 4.79 & 0.85 & 0.01 & 5.01 & 0.92 \\
\hline
\end{tabular}

Linear regression adjusted for sex, BMI (model 1), and linear regression adjusted for sex, body mass index (BMI), morbidity index and CMV status (model 2). SE (standard error). Significant associations are highlighted in bold 
of Treg cells has been characterized in human obese omental adipose tissue [43]. Another recent study revealed an impaired NK cell phenotype and NK cell subset alterations in obese individuals [44]. Reduced circulating Treg cell numbers were detected in obese compared with non-obese study participants [41], and another study identified a significant inverse correlation of Th2 cells in peripheral blood with systemic insulin resistance [12]. Additionally, our group found recently that insulin resistance correlates significantly with a shift in the ratio of naïve and differentiated memory $\mathrm{CD} 4^{+}$and $\mathrm{CD}^{+} \mathrm{T}$ cells in abdominal subcutaneous adipose tissue in female obese subjects [18]. Furthermore, it has been found that peripheral frequencies of T-helper (Th)22 cells and IL-22 levels were increased in obese subjects with or without type 2 diabetes compared with lean subjects, and that Th22 cell frequencies correlated positively with HOMA-IR [40]. These findings were confirmed in another study, showing that Th22 and Th17 cells were elevated in abdominal subcutaneous adipose tissue from metabolically abnormal IR obese compared with metabolically normal IS obese subjects [45]. Although the association of obesity with systemic low-grade inflammation is well established, immunological studies on the characteristics of IS versus IR metabolically unhealthy obese individuals are limited.

Here, we have investigated the association of insulin resistance and immunological parameters in a sample of 437 older participants of the BASE-II study. We analyzed peripheral blood immune cell subsets and cytokine levels with multiparameter flow cytometry analysis. We found that frequencies of naïve $\mathrm{CD} 4^{+}$and $\mathrm{CD} 8^{+} \mathrm{T}$ cells correlated positively with ISI $_{\text {OGTT }}$, but negatively with BMI and HOMA-IR, whereas frequencies of central memory $\mathrm{CD}^{+} \mathrm{T}$ cells correlated negatively with ISI $_{\mathrm{OGTT}}$, but positively with BMI and HOMA-IR. Additionally, the percentage of highly differentiated effector memory $\mathrm{CD}^{+} \mathrm{T}$ cells was positively associated with HOMA-IR, and the expression of CD57, a surface marker putatively associated with impaired proliferation capacity, immunoregulation, and cell senescence [21], correlated positively with BMI and HOMA-IR in older participants of this study. However, the expression of $\mathrm{PD}-1$, a characteristic marker for $\mathrm{T}$ cell exhaustion, on $\mathrm{CD}^{+} \mathrm{T}$ cells was not associated with metabolic measures (Supplementary Table 1). In line with previous reports [20,46], we also identified a positive association of systemic IL-6 levels with insulin resistance, whereas other cytokines (IL-1ß, TNF, IL-10) did not correlate significantly (Fig. 1). Cytokines can be used as target biomarkers for immune response and inflammaging. Recently, IL-6, which is known to be a main stimulator of the production of acute-phase proteins, was shown to be elevated with advanced age in a sample of healthy people and correlated with BMI and CRP levels [47]. IL-6 has pleiotropic effects on inflammation, immune response, and hematopoiesis, but dysregulated synthesis of IL-6 plays a pathological effect on chronic inflammation and autoimmunity. To address the association of $\mathrm{MHO}$ with insulin resistance, we divided the study participants in obese and non-obese IR and IS subgroups, based on $\mathrm{ISI}_{\mathrm{OGTT}}$. The increased frequencies of peripheral blood $\mathrm{CD} 4^{+} \mathrm{T}$ cells in IS obese and non-obese individuals were accompanied by a selective increase of naïve $\mathrm{CD}^{+} \mathrm{T}$ cells. Similarly, in the $\mathrm{CD} 8^{+} \mathrm{T}$ cell compartment, the frequencies of naïve $\mathrm{T}$ cells were higher in IS obese and non-obese subgroups, whereas effector memory $\mathrm{T}$ cells were significantly lower. Altogether, the $\mathrm{CD} 4^{+}$and $\mathrm{CD} 8^{+}$ $\mathrm{T}$ cell compartment was skewed towards a senescentlike $\mathrm{T}$ cell phenotype in IR subjects (Fig. 2, Supplementary Table 3-4). Additionally, the frequencies of naïve $\mathrm{CD}^{+}$and $\mathrm{CD}^{+} \mathrm{T}$ cells were predictive for $\mathrm{ISI}_{\mathrm{OGTT}}$, and the relationship of $\mathrm{ISI}_{\mathrm{OGTT}}$ with naive $\mathrm{CD} 4^{+} \mathrm{T}$ cells remained significant after adjustment for sex, BMI, clinical conditions (morbidity index) and CMV-serostatus (Table 2).

Here, we investigated the association of insulin resistance with immune cell parameters in older study participants and defined IS participants that were not treated with antidiabetic medication as "metabolically healthier", but the definition of MHO is still controversial. Recently, the following criteria have been proposed in addition to the diagnosis of obesity (BMI $\left.>30 \mathrm{~kg} / \mathrm{m}^{2}\right)$ fasted serum triglycerides $\leq 1.7 \mathrm{mmol} / \mathrm{l}(\leq 150 \mathrm{mg} / \mathrm{dl}) ;$ HDL cholesterol serum concentrations $>1.0(>40 \mathrm{mg} / \mathrm{dl})$ (in men) or $>$ $1.3 \mathrm{mmol} / \mathrm{l}$ (>50 mg/dl) (in women); systolic blood pressure (SBP) $\leq 130 \mathrm{mmHg}$; diastolic blood pressure $\leq 85$ $\mathrm{mmHg}$; fasting blood glucose $\leq 6.1 \mathrm{mmol} / \mathrm{l}(\leq 100 \mathrm{mg} / \mathrm{dl})$; no drug treatment for dyslipidemia, diabetes, or hypertension; and no cardiovascular disease manifestation [7]. The number of BASE-II participants that would have met all criteria was extremely low, which can be attributed to their age, for which reason we only assessed parameters for insulin sensitivity and insulin resistance for further analyses. Interestingly, frequencies of systemic naive $\mathrm{CD} 4^{+}$and $\mathrm{CD} 8^{+} \mathrm{T}$ cells of older participants of the BASE-II study, were positively associated with HDL cholesterol serum concentrations, whereas associations with fasting blood glucose and fasted serum triglycerides were negative (data not shown).

Our study has several important limitations. First, we could only include a small subgroup of BASE-II study participants based on the availability of flow cytometric data and cytokine level measurements of blood samples. Although the distribution of the analyzed subgroup is similar to the whole cohort (e.g. equal gender distribution), the sample size is rather small after further subdivision into obese and non-obese, IS and IR groups, and 
the different numbers of IS $(n=243)$ versus IR $(n=84)$ non-obese participants could limit the power to detect significant associations. However, the sample size of obese IS $(n=28)$ and IR $(n=32)$ participants is similar, and regarding the multiparameter flow cytometry analysis we conducted, the sample size is still reasonable. Moreover, the relative homogeneity of the participants with regard to age (65-80 years) could strengthen our study; age-related changes in immune function and $\mathrm{T}$ cell alterations have been described previously [25, 28].

Second, we measured insulin sensitivity using

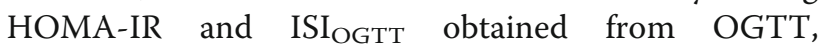
whereas the hyperinsulinemic-euglycemic clamp technique is considered the most reliable method available for estimating insulin resistance and is used as reference standard. In the present study, only half of the obese subgroup was considered IR with $\mathrm{ISI}_{\mathrm{OGTT}}<4$ and $32 \%$ of the obese subgroup was considered IR with HOMA-IR $<2.9$. On the other hand, $19 \%$ of the non-obese subgroup was considered IR with ISI $_{\mathrm{OGTT}}<$ 4 , and $4.6 \%$ with HOMA-IR $>2.9$, which might be explained by significantly higher BMI in the IR nonobese subgroup. Due to significant inter laboratory variations in insulin assays, the normal range of these parameters needs to be established for each laboratory and could also explain differences in the percentages of participants considered IR, here. However, the measurements of HOMA-IR and ISI OGTT $_{\text {are minim- }}$ ally invasive, and, thus, still suitable for clinical uses. Moreover, these surrogate parameters of insulin resistance are widely used in observational studies which allows for comparison between different studies.

Third, we assessed peripheral blood immune cell frequencies in this study, which often correlate with immune cell profiles in adipose tissues [12], but further investigation on immune cell parameters in abdominal subcutaneous and visceral adipose tissue and adipose tissue dysfunction [48] is needed to elucidate biological mechanisms linking obesity to insulin resistance.

\section{Conclusions}

In conclusion, our study underscores the role of immunological parameters in the differentiation of IS from IR individuals with obesity. Our results suggest that the peripheral blood $\mathrm{T}$ cell compartment of IS individuals is characterized by higher frequencies of naïve $\mathrm{CD}^{+}$and $\mathrm{CD}^{+} \mathrm{T}$ cells, whereas differentiated and activated memory $\mathrm{CD}_{4}^{+}$and $\mathrm{CD}^{+} \mathrm{T}$ cell frequencies are lower than in IR individuals. Further studies are needed to explore mechanisms underlying the relationship between $\mathrm{T}$ cell senescence and insulin resistance in obesity, and to characterize immunological parameters of $\mathrm{MHO}$ to guide risk-stratified obesity treatment.

\section{Methods}

\section{Study population}

We analyzed a subgroup of 437 participants of the BASE-II study selected based on the availability of immune cell parameters, randomly selected from all 1600 participants (Table 1). BASE-II is a prospective multidisciplinary and multi-institutional study that investigates factors associated with aging trajectories in Berlin [4951]. Phenotypic assessments include factors related to geriatrics and internal medicine, immunology, genetics, psychology, sociology, and economics. Initial medical assessments included 2171 participants $(\sim 75 \%$ aged $60-84$ years and $\sim 25 \%$ aged $20-35$ years) [52]. Based on the $\mathrm{BMI}$ and the $\mathrm{ISI}_{\mathrm{OGTT}}$, we divided the participants into four groups: obese and non-obese $\left(\mathrm{BMI}>30 \mathrm{~kg} / \mathrm{m}^{2}\right.$ and $\left.\mathrm{BMI}<30 \mathrm{~kg} / \mathrm{m}^{2}\right)$ and IR $\left(\mathrm{ISI}_{\mathrm{OGTT}}<4\right)$ and IS (ISI ${ }_{\text {OGTT }}>$ 4). Medication use was initially assessed by a study physician. Patients with antidiabetic medications like metformine, sulfonylureas, thiazolidinediones and metiglinides were ruled out from the analyses. All participants gave written informed consent to the study protocol which was approved by the Ethics Committee of the CharitéUniversitätsmedizin Berlin (number of the ethical approval: EA2/ 029/09).

\section{Biochemical measurements}

A peripheral venous blood sample of all BASE-II participants was drawn in the morning after an overnight fast $\left(>8 \mathrm{~h}\right.$ ) and kept at $4{ }^{\circ} \mathrm{C}$ until analysis on the same day. Serum concentrations of total cholesterol, low-density lipoprotein, cholesterol, high-density lipoprotein cholesterol, and triglycerides were measured using enzymatic colorimetric tests or photometric measurements. Additionally, venous blood samples were taken for complete blood count. Glucose levels (fasting and 2-h post load) were measured using photometric methods and insulin levels were determined by an electrochemiluminescence immunoassay (Elecsys ${ }^{\circ}$ Insulin, Cobas/Roche). HbA1c was measured using high-performance chromatography (VARIANT II TURBO HbA1c Kit - 2.0, Bio-Rad). Insulin resistance was determined using the HOMA-IR (calculated as the product of fasting glucose and fasting insulin divided by 22.5). Moreover, insulin sensitivity was estimated by calculating ISI $_{\text {OGTT }}$ based on the work of Matsuda and colleagues [53]. CRP levels were determined using an immunological turbidity assay (cobas/Roche, Rotkreuz, Switzerland), as described previously [54].

\section{Additional data}

Body weight was measured with a portable electronic scale to the nearest $0.1 \mathrm{~kg}$ and height was determined to the nearest $0.1 \mathrm{~cm}$ by using an electronic weighing and measuring station (seca 764, seca, Hamburg, Germany). Weight and height were used for calculating the BMI, 
$\mathrm{kg} / \mathrm{m}^{2}$. Morbidity was assessed as a morbidity index based on most of the categories of the comorbidity index originally described by Charlson and collaborators [55], which is a weighted sum of moderate to severe, mostly chronic illnesses, including cancer (e.g., lymphoma) and cardiovascular (e.g., congestive heart failure) and metabolic diseases (e.g., diabetes mellitus). The morbidity index used in BASE-II has been described previously in detail [56].

\section{Flow cytometry on peripheral blood mononuclear cells}

Venous blood was taken from the participants of the BASE-II study during medical examinations at the Charité in Berlin and sent to the BASE-II partner site at the University Tübingen in EDTA tubes $(7 \mathrm{ml})$ packed in iso-containers, to minimize temperature variations. The peripheral blood mononuclear cells (PBMC) were further isolated under sterile conditions and frozen at $196^{\circ} \mathrm{C}$ in liquid nitrogen until further processing. Flow cytometry surface staining was performed as described previously [57]. First, PBMCs were treated with human Ig, GAMUNEX (Bayer, Leverkusen, Germany), and ethidium monoazide (EMA) bromide (MoBiTec $\mathrm{GmbH}$, Göttingen, Germany) for 10 min on ice to block nonspecific binding of antibodies and label dead cells. Cells were stained for $20 \mathrm{~min}$ on ice. Monoclonal antibodies used for flow cytometry are listed in Supplementary Table 8. Cells were then washed and analyzed immediately on a LSR II cytometer (BD, Heidelberg) with FACS Diva software (BD Biosciences). Data were analyzed using FlowJo 7.6.5 software (Tree Star, Portland, USA). T-cell subsets were characterized according to previously published models [58]. In brief, viable lymphocytes were gated within the $\mathrm{CD}^{+}$gate and then selected for either $\mathrm{CD}^{+}$or $\mathrm{CD}^{+}{ }^{+} \mathrm{T}$ cell subsets, which were further subdivided into main $T$ cell phenotypes $\left(T_{\text {Naive }}, T_{C M}, T_{E M}\right.$ and $\mathrm{T}_{\mathrm{EMRA}}$ ) characterized by expression of CD45RA, CCR7, CD27 and CD28. The distinct subsets of CD4 ${ }^{+}$ and $\mathrm{CD}^{+} \mathrm{T}$ cells were defined as follows: naïve $\mathrm{T}$ cells $\left(\mathrm{T}_{\mathrm{NAIVE}}\right.$, $\mathrm{CD} 45 \mathrm{RA}^{+} \mathrm{CCR} 7^{+} \mathrm{CD} 27^{+} \mathrm{CD} 28^{+}$), central memory $\mathrm{T}$ cells $\left(\mathrm{T}_{\mathrm{CM}}, \mathrm{CD} 45 \mathrm{RA}^{-} \mathrm{CD} 27^{+} \mathrm{CD} 28^{+}\right)$, effector memory $\mathrm{T}$ cells $\left(\mathrm{T}_{\mathrm{EM}}, \mathrm{CD} 45 \mathrm{RA}^{-} \mathrm{CD} 27^{-} \mathrm{CD} 28^{-}\right)$, and terminally differentiated effector memory $\mathrm{T}$ cells ( $\mathrm{T}_{\mathrm{EMRA}}$, $\mathrm{CD}^{2} 5 \mathrm{RA}^{+} \mathrm{CCR}^{-} \mathrm{CD}^{-} 7^{-} \mathrm{CD} 28^{-}$). Additionally, $\mathrm{T}_{\text {Naive }}$ cells have been gated for $\mathrm{CD} 95$ expression to identify TSCM $\left(\mathrm{CD} 45 \mathrm{RA}^{+}{ }^{\mathrm{CCR}} 7^{+} \mathrm{CD} 95^{+} \mathrm{CD} 27^{+} \mathrm{CD} 28^{+}\right.$) cells and PD-1 (CD279) expression was determined within the $\mathrm{CD}^{+}$ population. Treg cells were defined as FoxP $3^{+} \mathrm{CD} 25^{\text {high }}$ cells within the $\mathrm{CD} 4^{+}$or $\mathrm{CD} 8^{+} \mathrm{T}$ cell subset, as described previously [59]. The gating strategy for $\mathrm{T}$ cells is shown in Supplementary Figure 1 and Supplementary Figure 2. B cells were defined as viable $\mathrm{CD} 45^{+} \mathrm{CD} 19^{+} \mathrm{CD} 3^{-}$cells and were further divided into naïve and memory $\mathrm{B}$ cells based on the expression of IgD and CD27. NK cells were defined as viable $\mathrm{CD} 45^{+} \mathrm{CD} 14^{-} \mathrm{CD} 3^{-} \mathrm{CD} 56^{+}$cells, and monocytes were defined as viable $\mathrm{CD} 45^{+} \mathrm{CD} 14^{+}$cells. The gating strategy for B cells has been reported elsewhere [57]. Flow cytometry staining and data analysis were performed on blinded samples.

\section{Cytokine analysis}

Serum cytokine levels were determined as described previously $[31,60]$. Briefly, cytokine levels of IL-1ß, IL-6, IL-10 and TNF were determined using the high sensitivity CBA flex system (BD Biosciences), according to the manufacturer's instructions. Samples were measured (BD LSR-II) and consistent performance was assured using BD CS\&T beads.

\section{CMV serology}

Anti-CMV IgG titres were analyzed using a CMV IgG Kit (Omega Diagnostics Group, Scotland, UK) as described previously [54]. IgG levels were measured using a semi-quantitative approach, according to the manufacturer's instructions.

\section{Statistical analysis}

The results are shown as median 25th, and 75th percentile for continuous variables or as absolute numbers and percentages for categorical variables unless otherwise noted. All statistical analyses were performed with IBM SPSS Statistics software package, version 25 and GraphPad Prism version 8 (GraphPad Software, San Diego, CA). A one-sample Kolmogorov-Smirnov test was used to test variables for Gaussian distribution. The spearman rank correlation coefficient was used for analyzing bivariate correlations between the ISI $\mathrm{OGTT}_{\text {and }}$ immune cell subsets and cytokine levels. The Mann-Whitney $U$ test was applied to estimate differences between groups. Associations of systemic immune cell subsets and cytokine levels with metabolic measures were analyzed by linear regression models adjusted for sex, BMI, CMV-serostatus and the morbidity index. Because data analyses were exploratory no adjustment was made for multiple testing and $p$ values were interpreted descriptively. An acceptable level of statistical significance was established a priori at $p<0.05$.

\section{Supplementary Information}

The online version contains supplementary material available at https://doi. org/10.1186/s12979-020-00211-y.

Additional file 1: Supplementary Table 1-8. The association of adaptive immune cell phenotypes with metabolically healthy obesity.

Additional file 2: Supplementary Figure 1. Gating strategy for $\mathrm{CD}^{+}$ $\mathrm{T}$ cells. Supplementary Figure $\mathbf{2}$ Gating strategy for $\mathrm{CD} 8^{+} \mathrm{T}$ cells.

\section{Abbreviations}

BASE-II: Berlin Aging Study II; BMI: Body mass index; HOMA-IR: Homeostasis model of assessment for insulin resistance; IR: Insulin resistant; IS: Insulin 
sensitive; ISIOGTr: Insulin sensitivity index; MHO: Metabolically healthy obesity; NR: Normal range; OGTT: oral glucose tolerance test; CRP: Plasma C-reactive protein; Treg cells: Regulatory T cells; TSCM: T Stem cell-like memory T cells

\section{Acknowledgements}

Thanks to all employees and participants of BASE-II who supported this study by their contributions, discussions, and cooperation.

\section{Authors' contributions}

GP, EST and ID conceived and designed the experiments. DG, NB, DS and JSK performed the research, collected and analyzed data. JS and HDV contributed to the interpretation of the results. DS and JSK wrote the paper. All authors read and approved the final manuscript.

\section{Funding}

The Berlin Aging Study II was supported by the German Federal Ministry of Education and Research (Bundesministerium für Bildung und Forschung, BMBF) under grant numbers \#16SV5536K, \#16SV5537, \#16SV5538, \#16SV5837, \#01UW0808, 01GL1716A, and 01GL1716B. Another source of funding is the Max Planck Institute for Human Development, Berlin, Germany. Open Access funding enabled and organized by Projekt DEAL.

\section{Availability of data and materials}

The datasets used and/or analyzed during the current study are available from the corresponding author on reasonable request.

\section{Ethics approval and consent to participate}

All participants gave written informed consent to the study protocol which was approved by the Ethics Committee of the Charité-Universitätsmedizin Berlin (number of the ethical approval: EA2/ 029/09).

\section{Consent for publication}

Not applicable.

\section{Competing interests}

The authors have no conflict of interest to declare.

\section{Author details}

${ }^{1}$ Charité-Universitätsmedizin Berlin, Corporate Member of Freie Universität Berlin, Humboldt-Universität zu Berlin, and Department of Endocrinology and Metabolism, Berlin Institute of Health, Chariteplatz 1, 10117 Berlin, Germany. ${ }^{2}$ Present Address: Dept. of Laboratory Medicine, University of California, San Francisco, HSW1201U, Box 0451, 513 Parnassus Ave, San Francisco, CA 94143-0451, USA. ${ }^{3}$ Fairfax Centre, Kidlington, UK. ${ }^{4}$ Clinic for Cardiology, Charité Universitätsmedizin Berlin, Berlin, Germany. ${ }^{5}$ Center for Cardiovascular Research (CCR), Department of Endocrinology and Metabolism, Charité-Universitätsmedizin Berlin, Berlin, Germany. ${ }^{6}$ German Center for Cardiovascular Research (DZHK), partner site Berlin, Berlin, Germany. ${ }^{7}$ Berlin Institute of Health (BIH) Center for Regenerative Therapies (BCRT), Charité Universitätsmedizin Berlin, Berlin, Germany. ${ }^{8}$ Berlin Center for Advanced Therapies (BeCAT), Charité - Universitätsmedizin Berlin, Berlin, Germany. ${ }^{9}$ Institute of Medical Immunology, Charité - Universitätsmedizin Berlin, Berlin, Germany. ${ }^{10}$ Department of Immunology, University of Tübingen, Tübingen, Germany. "Health Sciences North Research Institute, Sudbury, ON, Canada.

Received: 26 July 2020 Accepted: 30 November 2020

Published online: 21 December 2020

\section{References}

1. Flier JS. Obesity wars: molecular Progress confronts an expanding epidemic. Cell. 2004;116(2):337-50.

2. Guh DP, Zhang W, Bansback N, Amarsi Z, Birmingham CL, Anis AH. The incidence of co-morbidities related to obesity and overweight: a systematic review and meta-analysis. BMC Public Health. 2009;9:88.

3. Akil L, Ahmad HA. Relationships between obesity and cardiovascular diseases in four southern states and Colorado. J Health Care Poor Underserved. 2011;22(4 Suppl):61-72.

4. Després J-P, Lemieux I. Abdominal obesity and metabolic syndrome. Nature. 2006;444:881.

5. Calle EE, Kaaks R. Overweight, obesity and cancer: epidemiological evidence and proposed mechanisms. Nat Rev Cancer. 2004;4:579.
6. Blüher M. The distinction of metabolically 'healthy' from 'unhealthy' obese individuals. Curr Opin Lipidol. 2010;21(1):38-43. https://doi.org/10.1097/MOL. Ob013e3283346ccc.

7. Blüher M. Metabolically Healthy Obesity. Endocr Rev. 2020;41(3):bnaa004.

8. Neeland IJ, Ross R, Després J-P, Matsuzawa Y, Yamashita S, Shai I, et al. Visceral and ectopic fat, atherosclerosis, and cardiometabolic disease: a position statement. Lancet Diab Endocrinol. 2019;7(9):715-25.

9. Müller MJ, Geisler C. Defining obesity as a disease. Eur J Clin Nutr. 2017: $71(11): 1256-8$.

10. van Vliet-Ostaptchouk JV, Nuotio M-L, Slagter SN, Doiron D, Fischer K, Foco $L$, et al. The prevalence of metabolic syndrome and metabolically healthy obesity in Europe: a collaborative analysis of ten large cohort studies. BMC Endocr Disord. 2014;14:9.

11. Lavie CJ, Laddu D, Arena R, Ortega FB, Alpert MA, Kushner RF. Healthy weight and obesity prevention: JACC health promotion series. J Am Coll Cardiol. 2018;72(13):1506-31.

12. McLaughlin T, Liu L-F, Lamendola C, Shen L, Morton J, Rivas H, et al. Tcell profile in adipose tissue is associated with insulin resistance and systemic inflammation in humans. Arterioscler Thromb Vasc Biol. 2014; 34(12):2637-43.

13. Shoelson SE, Lee J, Goldfine AB. Inflammation and insulin resistance. J Clin Invest. 2006;116(7):1793-801.

14. Exley MA, Hand L, O'Shea D, Lynch L. Interplay between the immune system and adipose tissue in obesity. J Endocrinol. 2014;223(2):R41-R8.

15. Ferrante AW. The Immune Cells in Adipose Tissue. Diabetes Obes Metab. 2013;15(0 3):34-8.

16. van Beek L, Lips MA, Visser A, Pijl H, loan-Facsinay A, Toes $R$, et al. Increased systemic and adipose tissue inflammation differentiates obese women with T2DM from obese women with normal glucose tolerance. Metabolism. 2014;63(4):492-501.

17. Klöting N, Fasshauer M, Dietrich A, Kovacs P, Schön MR, Kern M, et al. Insulin-sensitive obesity. Am J Physiol Endocrinol Metabol. 2010;299(3):E506E15.

18. Sbierski-Kind J, Mai K, Kath J, Jurisch A, Streitz M, Kuchenbecker L, Babel N Nienen M, Jürchott K, Spranger L, Jumpertz von Schwartzenberg R, Decker AM, Krüger U, Volk HD, Spranger J. Association between Subcutaneous Adipose Tissue Inflammation, Insulin Resistance, and Calorie Restriction in Obese Females. J Immunol. 2020;205(1):45-55. https://doi.org/10.4049/ jimmunol.2000108.

19. Feuerer M, Herrero L, Cipolletta D, Naaz A, Wong J, Nayer A, et al. Lean, but not obese, fat is enriched for a unique population of regulatory $T$ cells that affect metabolic parameters. Nat Med. 2009;15:930.

20. Spranger J, Kroke A, Möhlig M, Hoffmann K, Bergmann MM, Ristow M, Boeing H, Pfeiffer AF. Inflammatory cytokines and the risk to develop type 2 diabetes: results of the prospective population-based European Prospective Investigation into Cancer and Nutrition (EPIC)-Potsdam Study. Diabetes. 2003;52(3):812-7. https://doi.org/10.2337/diabetes.52.3.812.

21. Brenchley JM, Karandikar NJ, Betts MR, Ambrozak DR, Hill BJ, Crotty LE, et al. Expression of CD57 defines replicative senescence and antigen-induced apoptotic death of CD8+ T cells. Blood. 2003;101(7):2711-20.

22. Pangrazzi L, Reidla J, Carmona Arana JA, Naismith E, Miggitsch C, Meryk A, et al. CD28 and CD57 define four populations with distinct phenotypic properties within human CD8(+) T cells. Eur J Immunol. 2020;50(3):363-79.

23. Pangrazzi L, Weinberger B. T cells, aging and senescence. Exp Gerontol. 2020;134:110887.

24. Pangrazzi L, Naismith E, Miggitsch C, Carmona Arana JA, Keller M, GrubeckLoebenstein $\mathrm{B}$, et al. The impact of body mass index on adaptive immune cells in the human bone marrow. Immun Ageing. 2020;17(1):15.

25. Di Benedetto S, Derhovanessian E, Steinhagen-Thiessen E, Goldeck D, Müller L, Pawelec G. Impact of age, sex and CMV-infection on peripheral T cell phenotypes: results from the Berlin BASE-II study. Biogerontology. 2015; 16(5):631-43.

26. Tam BT, Morais JA, Santosa S. Obesity and ageing: two sides of the same coin. Obes Rev. 2020;21(4):e12991.

27. Fulop T, Witkowski JM, Pawelec G, Alan C, Larbi A. On the immunological theory of aging. Interdiscip Top Gerontol. 2014;39:163-76. https://doi.org/10. 1159/000358904.

28. Kverneland AH, Streitz M, Geissler E, Hutchinson J, Vogt K, Boës D, et al. Age and gender leucocytes variances and references values generated using the standardized ONE-study protocol. Cytometry Part A. 2016;89(6):543-64. 
29. Streitz M, Miloud T, Kapinsky M, Reed MR, Magari R, Geissler EK, et al. Standardization of whole blood immune phenotype monitoring for clinical trials: panels and methods from the ONE study. Transplant Res. 2013;2:17.

30. Müller L, Fülöp T, Pawelec G. Immunosenescence in vertebrates and invertebrates. Immun Ageing. 2013;10(1):12.

31. Tegeler C, O'Sullivan JL, Bucholtz N, Goldeck D, Pawelec G, SteinhagenThiessen $\mathrm{E}$, et al. The inflammatory markers CRP, IL-6, and IL-10 are associated with cognitive function - data from the Berlin aging study $\|$. Neurobiol Aging. 2016;38:112-7.

32. McNelis JC, Olefsky JM. Macrophages, immunity, and metabolic disease. Immunity. 2014;41(1):36-48. https://doi.org/10.1016/j.immuni.2014.05.010

33. Ferrante AW. Macrophages, fat, and the emergence of immunometabolism. J Clin Invest. 2013;123(12):4992-3.

34. Liu J, Divoux A, Sun J, Zhang J, Clément K, Glickman JN, et al. Genetic deficiency and pharmacological stabilization of mast cells reduce dietinduced obesity and diabetes in mice. Nat Med. 2009;15:940.

35. Talukdar S, Oh DY, Bandyopadhyay G, Li D, Xu J, McNelis J, et al. Neutrophils mediate insulin resistance in high fat diet fed mice via secreted elastase. Nat Med. 2012;18(9):1407-12.

36. Stefanovic-Racic M, Yang X, Turner MS, Mantell BS, Stolz DB, Sumpter $T L$, et al. Dendritic cells promote macrophage infiltration and comprise a substantial proportion of obesity-associated increases in CD11c $<$ sup $>+$ </sup> cells in adipose tissue and liver. Diabetes. 2012;61(9):2330-9.

37. Nishimura S, Manabe I, Nagasaki M, Eto K, Yamashita H, Ohsugi M, et al. CD8+ effector T cells contribute to macrophage recruitment and adipose tissue inflammation in obesity. Nat Med. 2009;15(8):914-20.

38. Winer DA, Winer S, Shen L, Wadia PP, Yantha J, Paltser G, et al. B cells promote insulin resistance through modulation of $\mathrm{T}$ cells and production of pathogenic IgG antibodies. Nat Med. 2011;17:610.

39. Onodera T, Fukuhara A, Jang MH, Shin J, Aoi K, Kikuta J, Otsuki M, Ishii M, Shimomura I. Adipose tissue macrophages induce PPARy-high FOXP3(+) regulatory T cells. Sci Rep. 2015;5:16801. https://doi.org/10.1038/srep16801.

40. Zhao R, Tang D, Yi S, Li W, Wu C, Lu Y, et al. Elevated peripheral frequencies of Th22 cells: a novel potent participant in obesity and type 2 diabetes. Plos One. 2014;9(1):e85770.

41. Wagner N-M, Brandhorst G, Czepluch F, Lankeit M, Eberle C, Herzberg S, et al. Circulating regulatory $T$ cells are reduced in obesity and may identify subjects at increased metabolic and cardiovascular risk. Obesity. 2013;21(3): 461-8.

42. Wu H, Ghosh S, Perrard XD, Feng L, Garcia GE, Perrard JL, et al. T-cell accumulation and regulated on activation, Normal T cell expressed and secreted Upregulation in adipose tissue in obesity. Circulation. 2007;115(8): 1029-38.

43. Wu D, Han JM, Yu X, Lam AJ, Hoeppli RE, Pesenacker AM, et al. Characterization of regulatory $T$ cells in obese omental adipose tissue in humans. Eur J Immunol. 2019;49(2):336-47.

44. Bähr I, Jahn J, Zipprich A, Pahlow I, Spielmann J, Kielstein H. Impaired natural killer cell subset phenotypes in human obesity. Immunol Res. 2018; 66(2):234-44.

45. Fabbrini E, Cella M, McCartney SA, Fuchs A, Abumrad NA, Pietka TA, Chen Z, Finck BN, Han DH, Magkos F, Conte C, Bradley D, Fraterrigo G, Eagon JC, Patterson BW, Colonna M, Klein S. Association between specific adipose tissue CD4+ T-cell populations and insulin resistance in obese individuals. Gastroenterology. 2013;145(2):366-74.e1-3. https://doi.org/10.1053/j.gastro. 2013.04.010.

46. Carey AL, Steinberg GR, Macaulay SL, Thomas WG, Holmes AG, Ramm G, et al. Interleukin-6 increases insulin-stimulated glucose disposal in humans and glucose uptake and fatty acid oxidation in vitro via AMP-activated protein kinase. Diabetes. 2006;55(10):2688-97.

47. Koelman L, Pivovarova-Ramich O, Pfeiffer AFH, Grune T, Aleksandrova K Cytokines for evaluation of chronic inflammatory status in ageing research: reliability and phenotypic characterisation. Immun Ageing. 2019;16(1):11.

48. Blüher M. Adipose tissue dysfunction contributes to obesity related metabolic diseases. Best Pract Res Clin Endocrinol Metab. 2013;27(2):163-77. https://doi.org/10.1016/j.beem.2013.02.005

49. Bertram L, Böckenhoff A, Demuth I, Düzel S, Eckardt R, Li S-C, et al. Cohort profile: the Berlin aging study II (BASE-II)†. Int J Epidemiol. 2013;43(3):70312

50. Gerstorf D, Bertram L, Lindenberger U, Pawelec G, Demuth I, SteinhagenThiessen E, Wagner G. G: Editorial. Gerontology. 2016;62:311-315. https://doi. org/10.1159/000441495.
51. Association of Thyroid Function with Handgrip Strength. Data from the study of health in Pomerania and the Berlin aging study II. Thyroid. 2019; 29(9):1220-6.

52. König M, Drewelies J, Norman K, Spira D, Buchmann N, Hülür G, et al. Historical trends in modifiable indicators of cardiovascular health and selfrated health among older adults: Cohort differences over 20 years between the Berlin Aging Study (BASE) and the Berlin Aging Study II (BASE-II). Plos One. 2018;13(1):e0191699-e.

53. Matsuda M, DeFronzo RA. Insulin sensitivity indices obtained from oral glucose tolerance testing: comparison with the euglycemic insulin clamp. Diabetes Care. 1999:22(9):1462-70.

54. Janssen N, Derhovanessian E, Demuth I, Arnaout F, Steinhagen-Thiessen E, Pawelec G. Responses of dendritic cells to TLR-4 stimulation are maintained in the elderly and resist the effects of CMV infection seen in the young. J Gerontol Series A. 2015:71(9):1117-23.

55. Charlson ME, Pompei $P$, Ales $K L$, Mackenzie CR. A new method of classifying prognostic comorbidity in longitudinal studies: development and validation. J Chronic Dis. 1987;40(5):373-83.

56. Meyer A, Salewsky B, Spira D, Steinhagen-Thiessen E, Norman K, Demuth I. Leukocyte telomere length is related to appendicular lean mass: crosssectional data from the Berlin Aging Study II (BASE-II). Am J Clin Nutr. 2016; 103(1):178-83. https://doi.org/10.3945/ajen.115.116806.

57. Goldeck D, Oettinger L, Janssen N, Demuth I, Steinhagen-Thiessen E, Pawelec G. Cytomegalovirus infection minimally affects the frequencies of B-cell phenotypes in peripheral blood of younger and older adults. Gerontology. 2016;62(3):323-9.

58. Derhovanessian E, Maier AB, Beck R, Jahn G, Hähnel K, Slagboom PE, et al. Hallmark features of immunosenescence are absent in familial longevity. J Immunol. 2010;185(8):4618-24

59. Weide B, Martens A, Zelba H, Stutz C, Derhovanessian E, Di Giacomo AM, et al. Myeloid-derived suppressor cells predict survival of patients with advanced melanoma: comparison with regulatory T cells and NY-ESO-1- or melan-A-specific T cells. Clin Cancer Res. 2014:20(6):1601-9.

60. Goldeck D, Pawelec G, Norman K, Steinhagen-Thiessen E, Oettinger L, Haehnel K, et al. No strong correlations between serum cytokine levels, CMV serostatus and hand-grip strength in older subjects in the Berlin BASE|| cohort. Biogerontology. 2016;17(1):189-98.

\section{Publisher's Note}

Springer Nature remains neutral with regard to jurisdictional claims in published maps and institutional affiliations.

Ready to submit your research? Choose BMC and benefit from:

- fast, convenient online submission

- thorough peer review by experienced researchers in your field

- rapid publication on acceptance

- support for research data, including large and complex data types

- gold Open Access which fosters wider collaboration and increased citations

- maximum visibility for your research: over $100 \mathrm{M}$ website views per year

At BMC, research is always in progress.

Learn more biomedcentral.com/submission 